\title{
Liter per Microgram per Hour
}

National Cancer Institute

\section{Source}

National Cancer Institute. Liter per Microgram per Hour. NCI Thesaurus. Code C85662.

Liters per microgram per hour. 